\title{
Sandpaper Wastes as Adsorbent for the Removal of Brilliant Green and Malachite Green Dye
}

\author{
Yasemin İşlek Coşkun, ${ }^{\star}$ Nur Aksuner and Jale Yanik \\ Department of Chemistry, Faculty of Science, Ege University, 35100 Bornova, Izmir, Turkey \\ * Corresponding author: E-mail: yasemin.islek@ege.edu.tr \\ Telephone number: +90(232)3115447 Fax: +90(232)3888294
}

Received: 11-29-2018

\begin{abstract}
Sandpaper wastes were used as adsorbent after pyrolysis at $500{ }^{\circ} \mathrm{C}$ and calcination at $800^{\circ} \mathrm{C}$ for the removal of brilliant green and malachite green cationic dye from an aqueous solution. The effects of the $\mathrm{pH}$, the adsorbent dose, the contact time, and the initial dye concentration on the removal efficiencies were investigated. The isotherm studies were conducted by using the Langmuir, Freundlich, and Dubinin-Radushkevich models, and thermodynamic studies were also performed. The adsorption of the Brilliant green and malachite green were found to comply with the Langmuir isotherm model and the Freundlich isotherm model, respectively. The thermodynamic studies showed that the adsorption of dyes were endothermic. The E values obtained from the Dubinin-Radushkevich isotherm showed that the adsorption mechanism was chemical in nature. Furthermore, the three kinetic models (pseudo first-order, pseudo second-order, and intraparticle diffusion) were investigated. It was found that the pseudo second-order kinetic model fitted well for adsorption of dyes.
\end{abstract}

Keywords: Adsorption; brilliant green; malachite green; dye removal; sandpaper.

\section{Introduction}

Brilliant green and malachite green are cationic (basic) dyes. Many industries such as paper, textile, furniture, and food industries use dyes for coloring purposes. ${ }^{1,2}$ Furthermore, in fish farming, brilliant green is used to protect fish from fungi, from parasites and from infections. However, the consumption of fish produced in this way is not recommended. ${ }^{2-5}$ Cationic dyes have toxic, carcinogenic and mutagenic properties. ${ }^{6}$ Significant risks arise after exposing these dyes to people. Therefore, the removal of the dyes prior to their discharge into the environment is crucial and essential.

Physical, chemical and biological methods are widely used for the removal of dyes from water. Among these methods, adsorption, the physical method has advantages such as simplicity, low cost, and ease of application. Natural materials (raw or activated forms of clay minerals), synthesized materials, nanomaterial based adsorbents, agricultural wastes and by-products (raw or modified leaf based materials, coffee wastes, peels) and industrial wastes and by-products (fly ash, aluminum oxides), and activated carbon are the most used adsorbents for dye removal. ${ }^{1,7-11}$ Cost is an important parameter for choosing the adsorbent. Low-cost adsorbents include natural, agricultural and industrial by product wastes ${ }^{12}$. Furthermore, the waste materials have little or no economic value and usually present a disposal problem. ${ }^{7}$ The use of these waste materials for the purpose of wastewater treatment can play a significant role in solving the disposal problems. Numerous inexpensive and abundant biosorbents especially agro waste materials, as well as industrial and municipal wastes, have been proposed by several researchers for the removal of malachite green and brilliant green dyes from aqueous solution. ${ }^{13}$ The usage of waste as an adsorbent helps to reduce environmental pollution by recycling. In the literature some of the low-cost adsorbents used for dye removal were $\mathrm{NaOH}$ treated saw dust, ${ }^{14}$ waste rubber tire, ${ }^{15}$ white rice husk ash, ${ }^{16}$ Neem leaf powder, ${ }^{17}$ kaolin, ${ }^{2}$ peach stone, ${ }^{18}$ and medical cotton waste ${ }^{19}$ etc.

Sandpaper is an abrasive used in the sanding process to correct the rough surfaces. It consists of sheets of paper or cloth with abrasive material glued with resin to one face. Formerly, sand and glass were used as abrasive surfaces, but nowadays materials such as aluminum oxide, zirconium oxide, and silicon carbide etc. are used. ${ }^{20}$ The storage and disposal of the sandpaper waste is a problem in terms of time, space, and cost. With this work, a useful area for sandpaper waste has been created, which will be beneficial for the environment and waste water remediation. 
The aim of the study is the removal of brilliant green and malachite green dyes from water by using sandpaper waste. Two adsorbents were prepared by applying pyrolysis and calcination process. To the best of our knowledge, it is the first study on brilliant green and malachite green removal using sandpaper waste based adsorbent. The important point of the study is that the pollution is reduced both by recycling of sandpaper waste, which is an industrial waste material and by removing the dyes from water. The effects of the experimental parameters such as the $\mathrm{pH}$, the adsorbent dose, the contact time and the initial dye concentration were examined. The isothermal models (Langmuir, Freundlich and Dubinin-Radushkevich), thermodynamic and kinetic parameters (pseudo first order, pseudo second order and intraparticle model) were also evaluated.

\section{Experimental}

\section{1. Materials and Apparatus}

All the reactive used was of an analytical grade. Distilled water was used throughout the study. Cationic dye Brilliant Green (BG) (CI 42040, MW: 462.65), malachite green oxalate (MG) (CI 42000, MW: 927.01) hydrochloric acid, sodium hydroxide, acetic acid, and sodium acetate were obtained from Merck. The chemical structure of brilliant green and malachite green are presented in Figure 1. The working dye solution was prepared daily by diluting $1000 \mathrm{mg} / \mathrm{L}$ stock dye solution. The spectrophotometric measurements were carried out by TG $80+$ model double beam UV/Vis spectrophotometer with PG Instruments. The $\mathrm{pH}$ was measured using a Mettler Toledo Five Go FG-2 pH meter. A Biosan OS-10 orbital shaker at $350 \mathrm{rpm}$ and Nuve ST-402 vibration water bath were used for the adsorption studies. The FTIR analyses of the adsorbents were carried out by using the Perkin Elmer 100 spectrum FT-IR spectrometer in the range of $4000-400 \mathrm{~cm}^{-1}$. The pore and surface morphology images were captured by using the Thermo Scientific Apreo S LoVac model scanning electron microscope (SEM). The chemical compositions of SW500 and SW800 were analyzed by X-ray Fluorescence spectrometer (Spectro Xepos, Ametec). BET analysis were executed by Quantachrome ASiQwin. The sandpaper was supplied by a fibre disk pad production company in Izmir, Turkey, as sheets.

\section{2. Preparation of Adsorbent from Sandpaper Wastes}

Two kind of adsorbent were obtained after pyrolysis and calcination processes. Pyrolysis and calcination processes were separately applied to the sandpaper sheets. The sandpaper sheets were cut into small pieces $(\leq 2 \mathrm{~cm})$ before the experiments. For pyrolysis, firstly, a quantity of 50 $\mathrm{g}$ of sandpaper was loaded into the reactor, and then the reactor was heated with a temperature rate of $7^{\circ} \mathrm{C}$ per minute up to $500{ }^{\circ} \mathrm{C}$ and held at this temperature for $1 \mathrm{~h}$. The reactor was continually purged with nitrogen at a flow rate of $25 \mathrm{~mL} / \mathrm{min}$. The nitrogen gas swept the volatile products from the reactor into the ice-cooled traps. The condensable volatiles, which were collected in the traps, were released. After pyrolysis, the furnace was cooled to room temperature in a nitrogen gas stream and the reactor content (carbonized residue) was withdrawn from the reactor. ${ }^{18}$ The obtained adsorbent was named SW500. Then, another part of the sandpaper sheets was calcined at $800{ }^{\circ} \mathrm{C}$ in a furnace up to $16 \mathrm{~h}$ and then stored in desiccators. The obtained adsorbent was named SW800.

\section{3. Adsorption Studies}

All of the adsorption studies were examined in batch mode. In order to find out the optimum experimental conditions, $25 \mathrm{~mL}$ of dye solutions were used. The initial concentration used was $20 \mathrm{mg} / \mathrm{L}$. The contact time was 24 $\mathrm{h}$ unless otherwise stated. In the $\mathrm{pH}$ study, the adsorbent amounts were $10 \mathrm{mg}$ for both adsorbents. The optimal sorbent doses were found to be $1.2 \mathrm{~g} / \mathrm{L}$ of SW500 and 0.4 $\mathrm{g} / \mathrm{L}$ of SW800 for the BG removal, while $2.4 \mathrm{~g} / \mathrm{L}$ for SW500 and $0.6 \mathrm{~g} / \mathrm{L}$ for SW800 for the MG removal after optimization study. The $\mathrm{pH}$ effect for the removal efficiencies was studied in the $\mathrm{pH}$ range between 3 and 10 . The initial $\mathrm{pH}$ of the solutions was adjusted to the desired value using $\mathrm{NaOH}$ or $\mathrm{HCl}$. The optimization studies, such as adsorbent dose $(0.2,0.4,0.6,1.2,1.8$ and $2.4 \mathrm{~g} / \mathrm{L})$, contact time $(1,5,10,15,20,40,60,120,180,240$, and $1440 \mathrm{~min})$, ini-
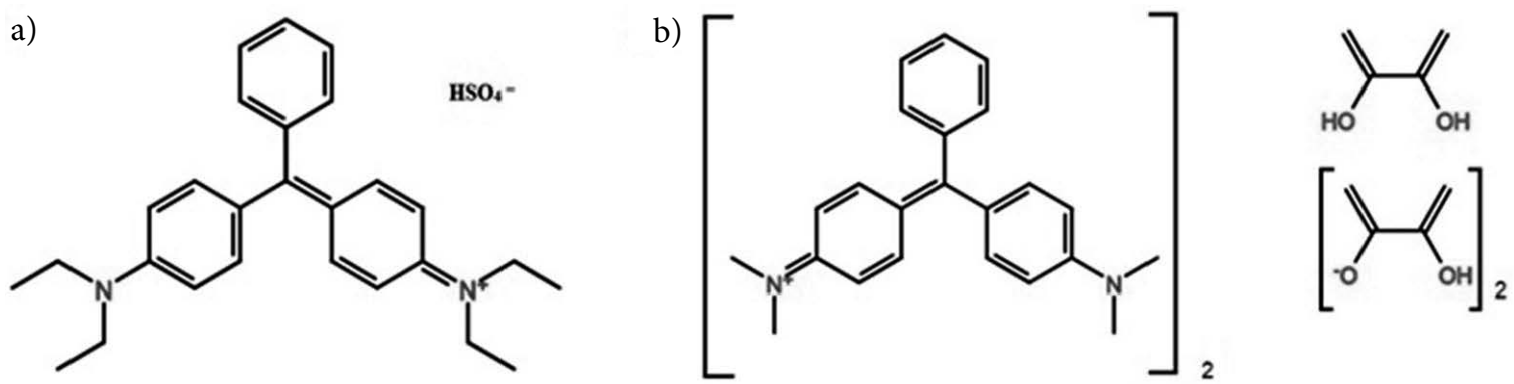

Figure 1. The chemical structure of brilliant green (a) and malachite green (b) 
tial dye concentrations $(5,10,25,50,100,200$, and 400 $\mathrm{mg} / \mathrm{L}$ ), and temperature ( $298 \mathrm{~K}, 303 \mathrm{~K}, 313 \mathrm{~K}$, and $323 \mathrm{~K}$ ) were performed. The adsorption isotherms were evaluated in the range of 5-500 $\mathrm{mg} / \mathrm{L}$ of dyes. Kinetic studies were investigated between 1-1440 min. The remaining BG and MG dye concentrations after sorption were measured at $624 \mathrm{~nm}$ and $617 \mathrm{~nm}$ by using UV-Vis spectrophotometer, respectively. All the experiments were conducted in triplicate. Before the spectrophotometric measurements, the $\mathrm{pH}$ of the dye solutions and standard solutions for the calibration were adjusted to 5.5 by using an acetic acid/acetate buffer. The removal efficiencies (R, \%) and adsorbed dye amounts (q, mg/g) were calculated, respectively;

$$
\begin{aligned}
& \mathrm{R}(\%)=\frac{(\mathrm{Ci}-\mathrm{Ce})}{\mathrm{Ci}} \times 100 \\
& \mathrm{q}=\frac{(\mathrm{Ci}-\mathrm{Ce})}{\mathrm{W}} \times \mathrm{V}
\end{aligned}
$$

Here, $\mathrm{Ci}$ and $\mathrm{Ce}$ are dye concentrations at an initial and equilibrium $(\mathrm{mg} / \mathrm{L}), \mathrm{w}$ is the amount of the adsorbent $(\mathrm{g})$, and $\mathrm{V}$ is the volume of the dye solutions (L).

\section{Results and Discussion}

\section{1. Characterization of the Sandpaper Waste Adsorbent}

The morphology of the bare SW500 and SW800 are depicted in Figure $2 \mathrm{a}$ and $2 \mathrm{~b}$, respectively. The morphology of the SW500 surface was irregular and porous. In Figure $2 b$, it was seen that the particles of SW800 were spherical and aggregate. The higher number of pores increased the adsorption of the dyes.

The FTIR spectra of the adsorbents before and after dye adsorption are shown in Figure $3 \mathrm{a}$ and $3 \mathrm{~b}$. In the spec-

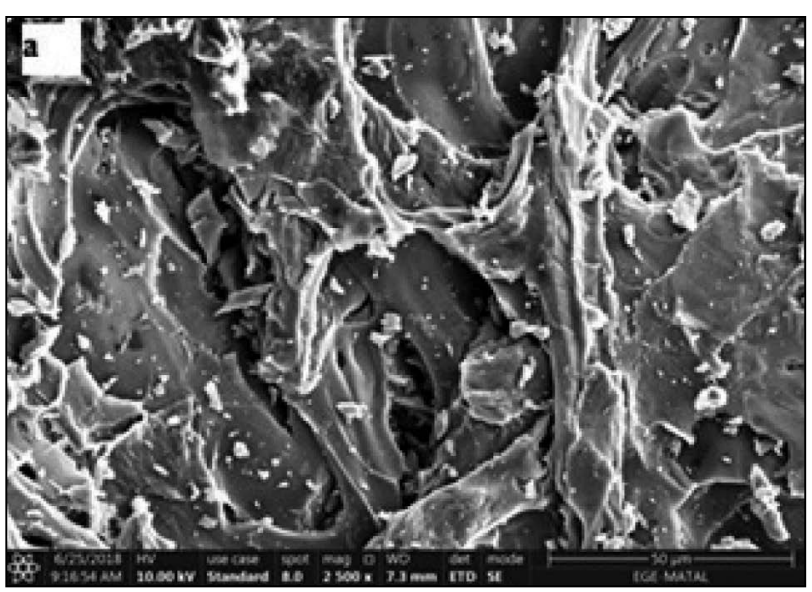

Figure 2. SEM images of bare adsorbents a) SW500 and b) SW800 trum of SW800, the peak at $3454.78 \mathrm{~cm}^{-1}$ could indicate $\mathrm{OH}$ stretching of the phenolic structure and crystal water. The intense peak at $1439.07 \mathrm{~cm}^{-1}$ was attributed to the aliphatic $\mathrm{C}-\mathrm{H}$ stretching band. The peaks belonging to the crystal water and aliphatic $\mathrm{C}-\mathrm{H}$ stretching band could also be seen in the other spectra. The two bands at 873.67 and $577.56 \mathrm{~cm}^{-1}$ could be $\mathrm{Al}-\mathrm{O}$ vibration bands in $\mathrm{Al}_{2} \mathrm{O}_{3}$. After the adsorption for both the adsorbents, the $\mathrm{C}=\mathrm{C}$ bands belonging to the aromatic ring of $\mathrm{BG}$ and $\mathrm{MG}$ appeared in the range of $1600-1700 \mathrm{~cm}^{-1}$. After BG adsorption on SW500, a peak assigning N-C band at $2969 \mathrm{~cm}^{-1}$ appeared. Besides, several adsorption peaks that emerged in the range of $1550-1380 \mathrm{~cm}^{-1}$ might be ascribed to the $\mathrm{N}-\mathrm{C}$ groups after BG adsorption on SW500..$^{13,14,21-26}$

The chemical compositions of SW500 and SW800 were determined by $\mathrm{X}$-ray fluorimeter. It was found that SW500 contained $1.43 \% \mathrm{Al}_{2} \mathrm{O}_{3}, 0.31 \% \mathrm{SiO}_{2}, 0.72 \% \mathrm{P}_{2} \mathrm{O}_{5}$, $0.16 \% \mathrm{SO}_{3}, 12.47 \% \mathrm{CaO}, 0.68 \% \mathrm{TiO}_{2}, 0.74 \% \mathrm{Fe}_{2} \mathrm{O}_{3}, 0.03 \%$ $\mathrm{CuO}, 0.24 \% \mathrm{ZnO}, 0.03 \% \mathrm{SrO}$ and $0.05 \% \mathrm{ZrO}_{2}$, while SW800 contained 3.6\% $\mathrm{Al}_{2} \mathrm{O}_{3}, 0.97 \% \mathrm{SiO}_{2}, 0.67 \% \mathrm{P}_{2} \mathrm{O}_{5}$, $0.16 \% \mathrm{SO}_{3}, 44.06 \% \mathrm{CaO}, 1.27 \% \mathrm{TiO}_{2}, 1.99 \% \mathrm{Fe}_{2} \mathrm{O}_{3}, 0.01 \%$ $\mathrm{CuO}, 0.03 \% \mathrm{ZnO}, 0.08 \% \mathrm{SrO}$ and $0.09 \% \mathrm{ZrO}_{2}$. The amount of $\mathrm{CaO}$ in SW800, which was prepared by calcination, was found higher than that of SW500. Furthermore, higher dye removal efficiencies were obtained for SW800 in the adsorption studies. Therefore, that result could be a conclusion of existence of higher amount of $\mathrm{CaO}$ in SW800. Metal oxides containing calcium oxides are well known adsorbents for removal of various effluent gas streams. Because they have high adsorption capacity, high surface reactivity, low cost, and abundant. ${ }^{27}$ Calcium mineral is also efficiently used for the dye removal in the literature. Calcium rich biochar from crab shell showed highly efficient removal for Malachite Green and Congo Red although it showed low specific surface area and total pore volume. ${ }^{28}$ Jung et al. have synthesized an adsorbent using spent coffee grounds (SCG) calcium alginate beads for the removal of acid orange 7 and methylene blue. It was expressed that it was difficult to remove powdered SCG-based activated

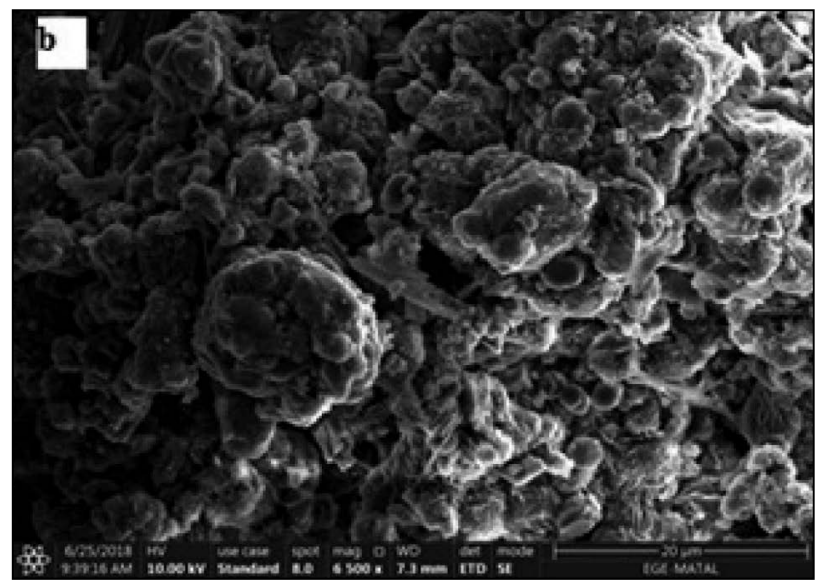


a)

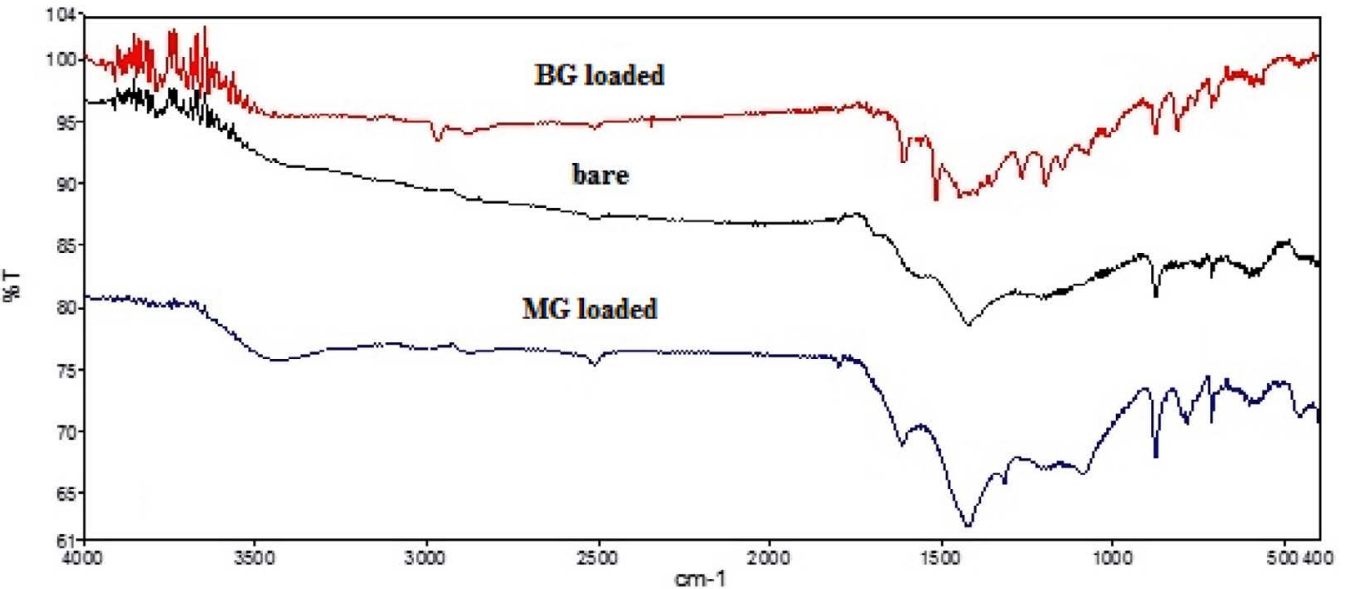

b)

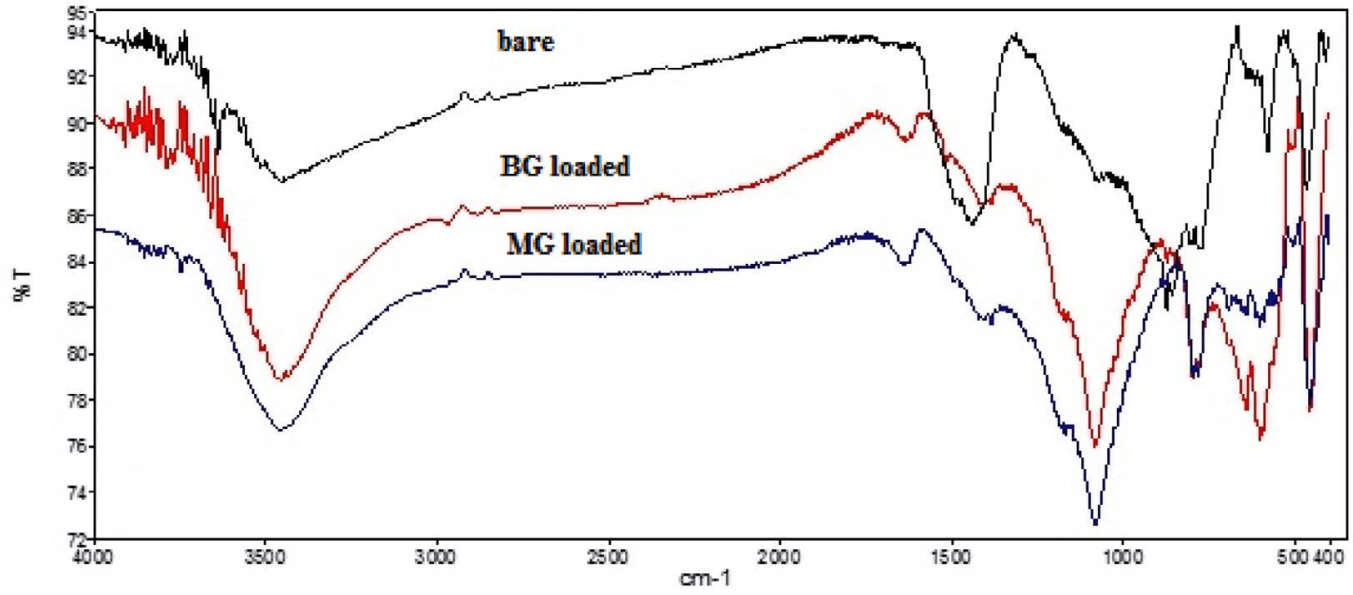

Figure 3. FTIR spectra of adsorbents before and after dye adsorption a) SW500 and b) SW800

carbon from aqueous solution after adsorption. Therefore, to form porous hydrogels beads powdered SCG based activated carbon was entrapped in calcium-alginate beads. It was reported that such heterogeneous surface might be take part in removal of dyes. ${ }^{29}$ Basic Green 4 was successfully removed by using sea shell powder. It was reported the shell contained protein, calcite and calcium carbonate crystals, and the adsorbent had heterogeneous pores and cavities that gave large surface area for dye removal. ${ }^{30}$ In study of Xia et al., it was expressed that the various metal oxides for the adsorption capacities of Congo red dye were increased in the following order: $\mathrm{NiO}<\mathrm{MnO}_{2}<\mathrm{Cr}_{2} \mathrm{O}_{3}<$ $\mathrm{Fe}_{2} \mathrm{O}_{3}<\mathrm{MgO}<\mathrm{CaO}^{27}$ Aguayo-Villarreal et al. clearly mentioned that the adsorption of acid blue 74, acid blue 25 and reactive blue 4 was governed by the calcium compounds existing in pecan shells. The electrostatic interactions between calcium ion and the sulphonyl groups of the dyes molecules were thought to be responsible for adsorption of dyes on pecan shells. ${ }^{31}$

The BET surface area, total pore volume and pore size were determined as $3.070 \mathrm{~m}^{2} / \mathrm{g}, 0.004354 \mathrm{~mL} / \mathrm{g}, 28.37$ $\mathrm{A}^{\circ}$ for SW500, and $1.103 \mathrm{~m}^{2} / \mathrm{g}, 0.001933 \mathrm{~mL} / \mathrm{g}, 35.04 \mathrm{~A}^{\circ}$ for SW800, respectively.

\section{2. Adsorption Studies for BG and MG Removal}

\section{2. 1. Effect of $\mathrm{pH}$ on $B G$ and MG Removal}

In order to define the optimum adsorption $\mathrm{pH}$, the $\mathrm{pHs}$ of the solutions were set in the range of 3-10 by 0.01 $\mathrm{mol} / \mathrm{L} \mathrm{HCl}$ and $\mathrm{NaOH}$. The removal efficiencies are shown in Figure 4. The optimum $\mathrm{pH}$ range of $\mathrm{BG}$ was found to be between 3 and 10, and the optimum $\mathrm{pH}$ of MG was in the range of 4-10 for SW800. The removal efficiencies of BG were reached to $96 \%$ at $\mathrm{pH} 5$, while the removal efficiencies of $\mathrm{MG}$ reached $91.4 \%$ at $\mathrm{pH} 7$ for SW 500 . The point of zero charge $\left(\mathrm{pH}_{\mathrm{pzc}}\right)$ was determined according to the following procedure. ${ }^{32} 25 \mathrm{~mL}$ of $0.1 \mathrm{~mol} / \mathrm{L}$ of $\mathrm{KNO}_{3}$ solution was adjusted to different $\mathrm{pH}$ values using $\mathrm{HCl}$ or $\mathrm{NaOH}$ and was added to the adsorbents. Thereafter, the suspension was shaken for $24 \mathrm{~h}$ to obtain the equilibrium $\mathrm{pH}$. The change of the $\mathrm{pH}$ during the equilibrium was calculated by subtracting the initial $\mathrm{pH}$ values from the final $\mathrm{pH}$ values. The $\Delta \mathrm{pH}$ values were then plotted against the initial $\mathrm{pH}$ values. The initial $\mathrm{pH}$ at which the $\Delta \mathrm{pH}$ was zero was taken to be the $\mathrm{pH}_{\mathrm{pzc}}$. The $\mathrm{pH}_{\mathrm{pzc}}$ values were 7.30 for SW500 and 10.1 for SW800. At 


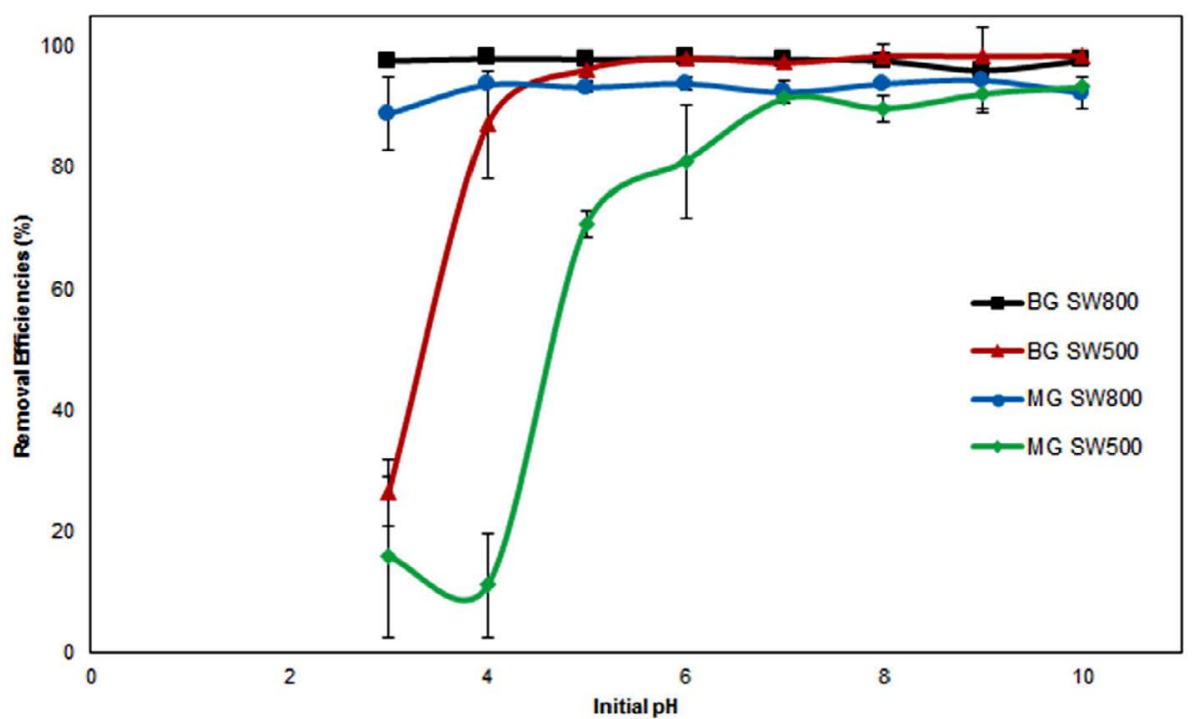

Figure 4. Effect of initial $\mathrm{pH}$ on the removal of BG and MG (adsorbent amount $10 \mathrm{mg}$, initial dye concentration $20 \mathrm{mg} / \mathrm{L}$, volume $25 \mathrm{~mL}$, contact time $24 \mathrm{~h}, \mathrm{pH}$ range $3-10, \mathrm{n}=3$ )

the $\mathrm{pH}$ values higher than $\mathrm{pHpzc}$, the surface charge was negative and attracted positively charged dye while at lower $\mathrm{pH}$ values, the surface charge was positive and attracted negatively charged dye. ${ }^{32,33}$ It was found that the final $\mathrm{pH}$ of the solutions at the end of the adsorption was found to be 7.5 after the initial $\mathrm{pH}$ of 5 for SW500, and about 10.8 for SW800 in all the studied initial pHs., Before the $\mathrm{pH}_{\mathrm{pzc}}$, the adsorption efficiencies of $\mathrm{BG}$ and $\mathrm{MG}$ for SW500 were as low as expected because of electrostatic repulsion. As seen in Figure 4, the adsorption efficiencies of BG were above $98 \%$ for SW500 after the initial pH of 5 (final solution pH 7.5 for SW500). In addition, the low adsorption observed for SW500 at pH below 5 may be due to the competition between $\mathrm{H}^{+}$ions and dye cations for the adsorbent's active sites. ${ }^{34}$ Furthermore, the same trend was observed for MG removal. Therefore, it was thought that electrostatic forces were effective for BG and MG removal. SW800 provided a wider working range than that of SW500 for BG and MG removal.

\section{2. 2. Effect of Adsorbent Dose on BG and MG Removal}

The effect of the sorbent dose was investigated in the range of $0.2-2.4 \mathrm{~g} / \mathrm{L}$. The results are presented in Figure 5. As seen in the Figure, for SW800, the removal efficiencies of BG in the studied range did not change significantly; therefore, the optimum dose was selected as $0.4 \mathrm{~g} / \mathrm{L}$. For SW500, the removal efficiencies of BG and MG increased slightly and then reaching a constant value of $1.2 \mathrm{~g} / \mathrm{L}$ and $2.4 \mathrm{~g} / \mathrm{L}$, respectively. The optimum sorbent dose was found to be $0.6 \mathrm{~g} / \mathrm{L}$ for MG removal for SW800. That situation

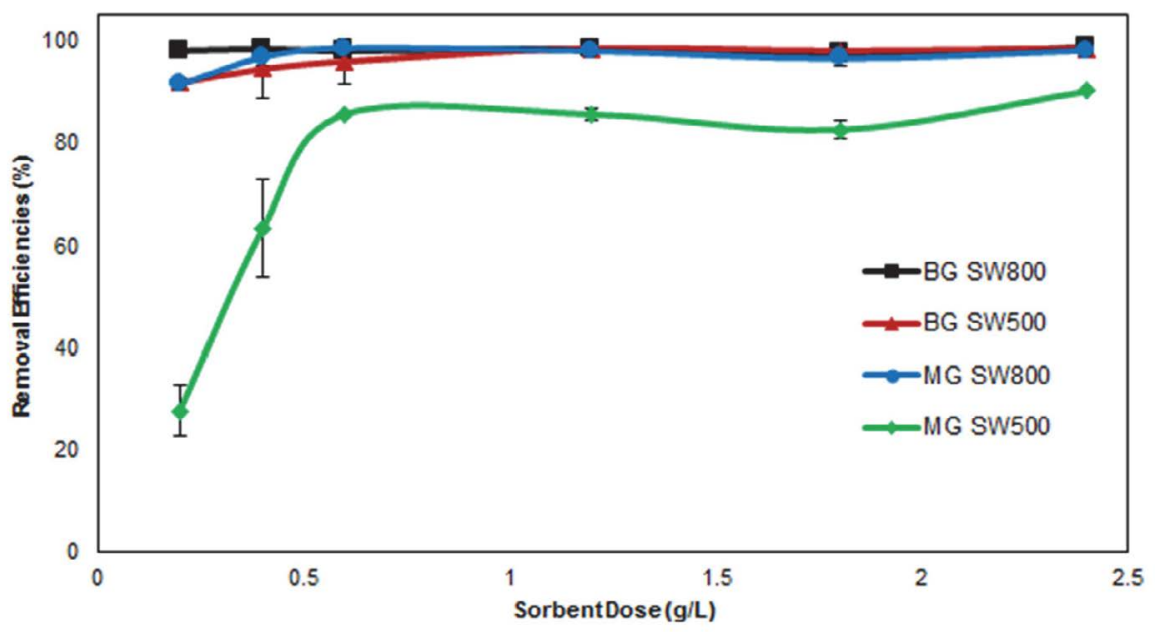

Figure 5. Effect of adsorbent dose on the removal of BG and MG (adsorbent dose range $0.2-2.4 \mathrm{~g} / \mathrm{L}$, initial dye concentration $20 \mathrm{mg} / \mathrm{L}$, volume $25 \mathrm{ml}$, contact time $24 \mathrm{~h}, \mathrm{n}=3$ ) 


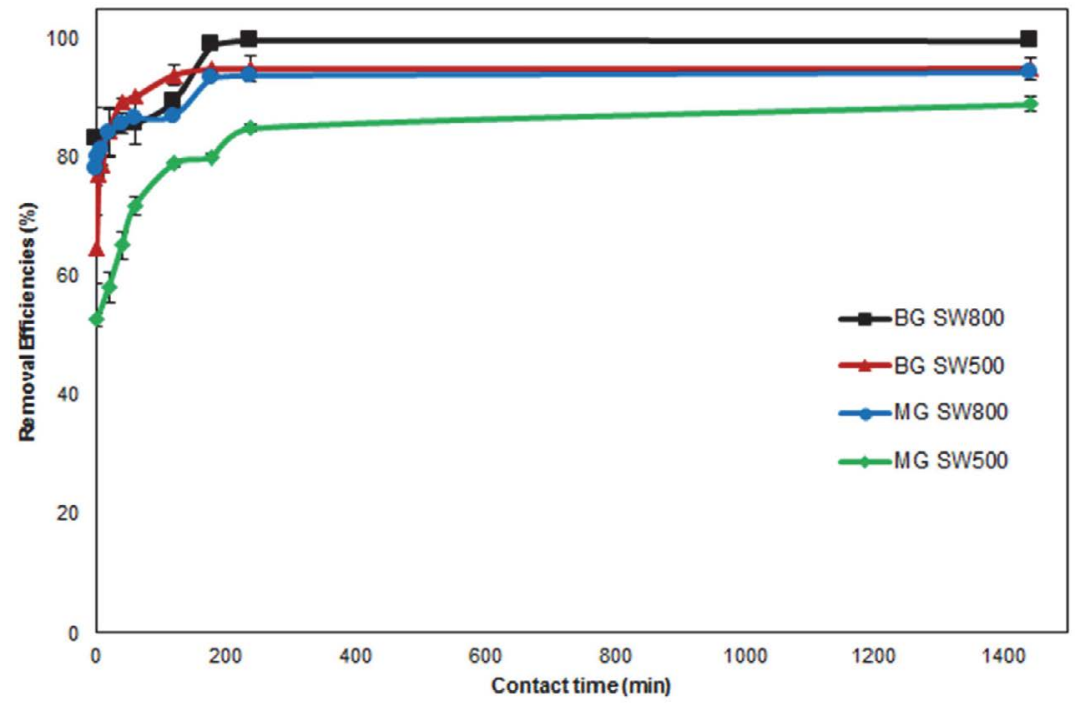

Figure 6. Effect of contact time on the removal of BG and MG (adsorbent dose of BG and MG: 0.4 and $0.6 \mathrm{~g} / \mathrm{L}$ for SW800 and, 1.2 and $2.4 \mathrm{~g} / \mathrm{L}$ for SW500, initial dye concentration $20 \mathrm{mg} / \mathrm{L}$, volume $25 \mathrm{~mL}$, contact time $1-1440 \mathrm{~min}, \mathrm{n}=3$ )

may be attributed to an increase in the number of active sites with the increase in the adsorbent dose $e^{2}$.

\section{2. 3. Effect of Contact Time on BG and MG Removal}

Figure 6 shows the effect of the contact time on the removal of BG and MG by SW500 and SW800 adsorbents in the range of 1-1440 min. It was observed that the adsorption equilibrium is reached faster for SW500 than for SW800 for BG removal. Within the first 40 minutes, $89 \%$ of BG dye was adsorbed by SW500 and reached $94 \%$ of the removal efficiency at $120 \mathrm{~min}$. Meanwhile, $90 \%$ of BG dye adsorption took place within 120 min and equilibrium was reached at 180 min with $98.8 \%$ of the removal efficiency for SW800. The optimum contact times of BG dye were selected to be $120 \mathrm{~min}$ and $180 \mathrm{~min}$ for SW500 and SW800, respectively. The optimum contact times of MG removal were found to be $180 \mathrm{~min}$ and $240 \mathrm{~min}$ for SW500 and SW800, respectively. Taking into account the adsorbent doses used in the study, SW800 was superior to SW500. At the initial contact time, the rapid increase in adsorption was explained by the excess of vacant areas on the adsorbent surface, and as the sorption continues, the adsorption rate decreases with the decrease of the active areas on the sorbent surface. ${ }^{3,14}$

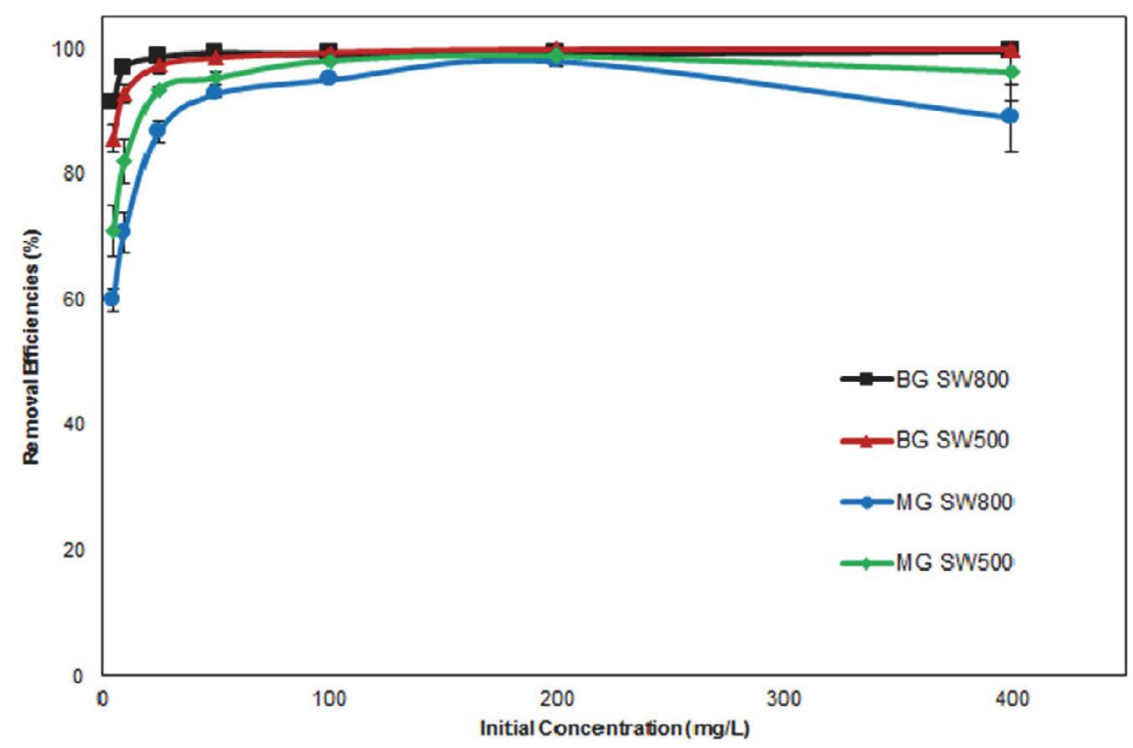

Figure 7. Effect of initial concentration on the removal of BG and MG (adsorbent dose of BG and MG: 0.4 and $0.6 \mathrm{~g} / \mathrm{L}$ for SW800 and, 1.2 and 2.4 $\mathrm{g} / \mathrm{L}$ for SW500, initial dye concentration range 5-400 mg/L, volume $25 \mathrm{~mL}$, contact time $24 \mathrm{~h}, \mathrm{n}=3$ ) 


\section{2. 4. Effect of Initial Concentration on BG and MG Removal}

The variations in removal efficiencies were investigated with initial dye concentrations ranging from 5 to 400 $\mathrm{mg} / \mathrm{L}$. The results are depicted in Figure 7. Sudden sharp increases were observed at the lower concentrations of BG and MG for both the adsorbents. The removal efficiencies became constant and then decreased at higher concentrations. It is thought that there is fixed number of available sites per unit mass of the adsorbent on the adsorbent surface. The number of available sites is higher for low initial dye concentration as against to the high initial concentration. Consequently, the most of the dye molecules are adsorbed by adsorbents at low initial dye concentrations and the removal efficiencies increases. On the other hand, when the certain initial dye concentrations is exceed, active sites of the adsorbent are completely retained, some of the dye molecules cannot be adsorbed, and the removal efficiencies become to decrease. ${ }^{2,35}$ The removal efficiencies of BG reached equilibrium by $100 \mathrm{mg} / \mathrm{L}$ with $99.4 \%$ and $50 \mathrm{mg} / \mathrm{L}$ with $99.3 \%$ for SW500 and SW800, respectively. The removal efficiencies of $\mathrm{MG}$ reached equilibrium by $100 \mathrm{mg} / \mathrm{L}$ with $98.1 \%$ and $100 \mathrm{mg} / \mathrm{L}$ with $95.5 \%$ for SW500 and SW800, respectively.

\section{2. 5. Thermodynamic Studies}

The effect of the temperature on BG and MG removal was investigated at $298,303,313$ and $323 \mathrm{~K}$. In order to calculate the thermodynamic parameters associated with the adsorption process, a change in Gibb's free energy $\left(\Delta \mathrm{G}^{\circ}\right)$, enthalpy $\left(\Delta \mathrm{H}^{\circ}\right)$ and entropy changes $\left(\Delta \mathrm{S}^{\circ}\right)$, used the equations below. The parameters exhibit spontaneity, randomness, and endothermicity/exothermicity of the adsorption processes.

$$
\begin{aligned}
& \ln K_{L}=-\frac{\Delta H^{0}}{R T}+\frac{\Delta S^{0}}{R} \\
& \Delta G^{0}=-R T \ln K_{L} \\
& \Delta G^{0}=\Delta H^{0}-T \Delta S^{0}
\end{aligned}
$$

$\Delta \mathrm{G}^{\circ}$ is the free energy change $(\mathrm{kJ} / \mathrm{mol}), \mathrm{R}$ is the gas constant $(8.314 \mathrm{~J} / \mathrm{mol} \mathrm{K}), \mathrm{K}_{\mathrm{L}}$ is the Langmuir equilibrium constant $(\mathrm{L} / \mathrm{mol}),{ }^{36}$ and $\mathrm{T}$ is the temperature $(\mathrm{K}) . \mathrm{K}_{\mathrm{L}}$ values were found from the ratio of the adsorbed dye concentration (mg) and equilibrium dye concentration in the solution $(\mathrm{mg} / \mathrm{L})$. The parameters of $\Delta \mathrm{H}$ and $\Delta \mathrm{S}$ were obtained from the slope and the intercept of the Van't Hoff graph between $\ln \mathrm{K}_{\mathrm{L}}$ and $1 / \mathrm{T}$, respectively. ${ }^{14}$

The negative value of $\Delta \mathrm{G}^{0}$ indicates the adsorption is spontaneous and favorable. $\Delta \mathrm{H}^{\circ}$ values are positive whether the adsorption is endothermic, or vice versa. The positive $\Delta S^{\circ}$ reveals that randomness increased at the solid-liquid interface. The positive $\Delta S^{\circ}$ also indicates the affinity of the adsorbent for BG and MG. ${ }^{37,38}$ The calculated thermodynamic parameters are depicted in Table 1 . As seen in Table 1 , the adsorptions of BG and MG by both adsorbents were endothermic, favorable, and spontaneous. It was understood that the degree of randomness increased during the adsorption $\left(\Delta \mathrm{S}^{\circ}>0\right)$. The value of $\Delta \mathrm{H}^{\circ}$ presents an idea about different physical forces being involved in the adsorption process such as van der Waals forces $(4-10 \mathrm{~kJ} / \mathrm{mol}$ ), hydrophobic bond forces $(5 \mathrm{~kJ} / \mathrm{mol})$, hydrogen bond forces $(2-40 \mathrm{~kJ} / \mathrm{mol})$, coordination exchange $(40 \mathrm{~kJ} / \mathrm{mol})$, dipole bond forces $(2-29 \mathrm{~kJ} / \mathrm{mol})$, and for chemical forces $(>60 \mathrm{~kJ} /$ mol). ${ }^{39}$ Our results indicated that the forces affecting the adsorption of BG could be hydrogen bond forces and dipole bond forces because of $\Delta \mathrm{H}^{\circ}$ values belonging to $\mathrm{BG}$ being calculated in our study as 2.65 and $28.50 \mathrm{~kJ} / \mathrm{mol}$ for SW800 and SW500, respectively. However, $\Delta \mathrm{H}^{\circ}$ values of MG were calculated to be 28.38 and $47.79 \mathrm{~kJ} / \mathrm{mol}$ for SW800 and SW500, respectively. Hence, it was thought that the adsorption of MG could be affected by hydrogen bond forces.

Table 1. Thermodynamic parameters for adsorption of BG and MG onto SW500 and SW800 $(n=3)$.

\begin{tabular}{lcccc}
\hline & $\mathbf{T}(\mathbf{K})$ & $\begin{array}{c}\Delta \mathbf{H}^{\circ} \\
(\mathbf{k J} / \mathbf{m o l})\end{array}$ & $\begin{array}{c}\Delta \mathbf{S}^{\circ} \\
(\mathbf{J} / \mathbf{m o l . K})\end{array}$ & $\begin{array}{c}\Delta \mathbf{G}^{\circ} \\
(\mathbf{k J} / \mathbf{m o l})\end{array}$ \\
\hline Brilliant Green & & & & \\
SW800 & 298 & 2.650 & 103.9 & -13.10 \\
& 303 & & & -13.36 \\
& 313 & & & -13.90 \\
SW500 & 323 & & & -14.42 \\
& 298 & 28.50 & 176.1 & -8.972 \\
& 303 & & & -9.372 \\
Malachite Green & 313 & & & -10.17 \\
SW800 & 323 & & & -10.97 \\
& 298 & 28.38 & 174.3 & -8.361 \\
& 303 & & & -8.977 \\
SW500w & 313 & & & -10.21 \\
& 323 & & & -11.44 \\
& 298 & 47.79 & 219.9 & -17.74 \\
& 303 & & & -18.84 \\
& 313 & & & -21.04 \\
& 323 & & & -23.24 \\
\hline
\end{tabular}

\section{2. 6. Isotherm Studies}

The isotherm studies display the way of interactions between the dye molecules and the adsorbent, and also provide information about the nature of interactions. Experimental data was applied to the Langmuir ${ }^{40}$ Freundlich and Dubinin Radushkevic (D-R) isotherm models. ${ }^{41}$ The Langmuir isotherm is based on the acceptance that the adsorption occurred at specific homogenous sites within the adsorbent while the Freundlich isotherm mentions the acceptance of a heterogeneous surface with a non-uniform distribution of heat of adsorption over the surface. ${ }^{38} \mathrm{D}-\mathrm{R}$ 


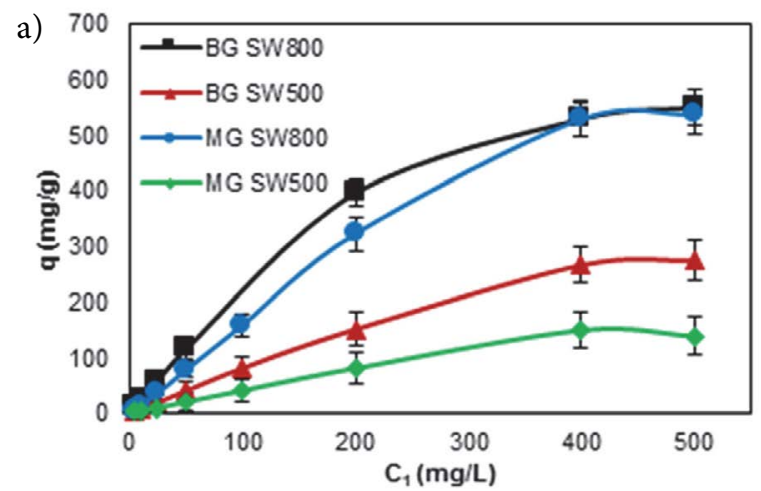

b)

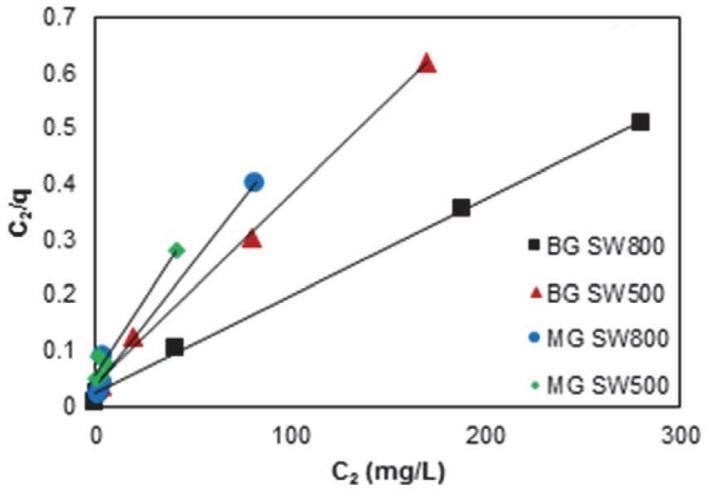

c)

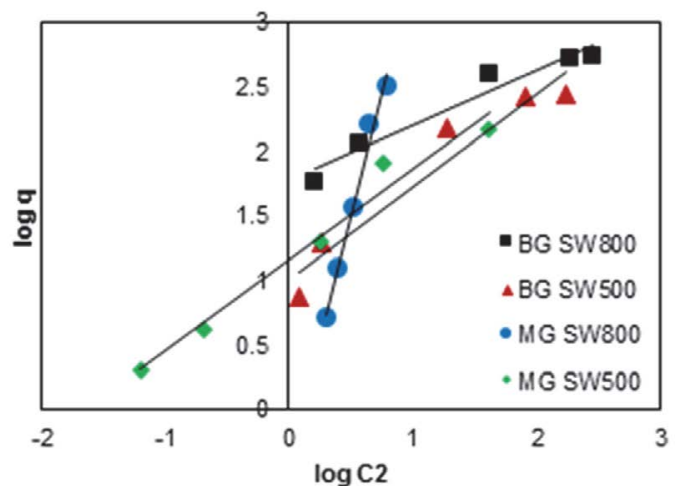

d)

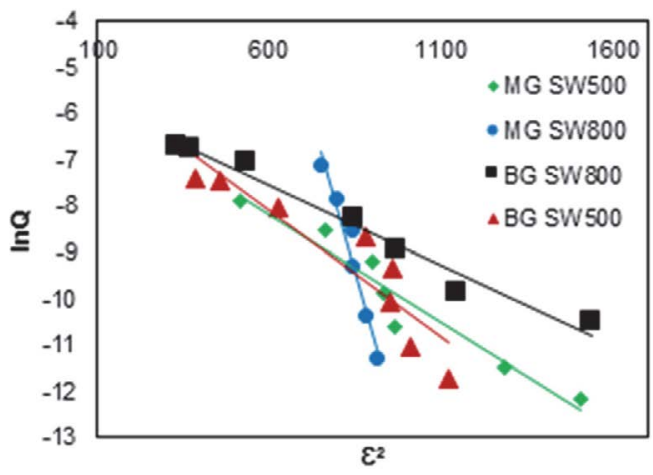

Figure 8. Adsorbed amount of dye as a function of initial concentration (a), Langmuir isotherms (b), Freundlich isotherms (c) and DR isotherms (d) for adsorption BG and MG, (initial dye concentration range 5-500 mg/L, volume $25 \mathrm{~mL}$, adsorbent dose of BG and MG: 0.6 and $0.4 \mathrm{~g} / \mathrm{L}$ for SW800 and, 1.2 and $2.4 \mathrm{~g} / \mathrm{L}$ for SW500, contact time $24 \mathrm{~h}, \mathrm{n}=3$ )

Table 2. The isotherm parameters of Langmuir, Freundlich, and DR isotherms for BG and MG adsorption using SW500 and SW800 ( $\mathrm{n}=3$ ).

\begin{tabular}{|c|c|c|c|c|c|}
\hline & & $\begin{array}{c}\text { Brilliant Green } \\
\text { SW800 }\end{array}$ & SW500 & $\begin{array}{c}\text { Malachite Green } \\
\text { SW800 }\end{array}$ & SW500 \\
\hline \multicolumn{6}{|l|}{ Langmuir Isotherm } \\
\hline$\frac{C_{2}}{q}=\left(\frac{1}{Q_{\max }}\right) C_{2}+\frac{1}{b Q_{\max }}$ & $\begin{array}{l}Q_{\max }(\mathrm{mg} / \mathrm{g}) \\
\text { b (L/mg) } \\
\mathbf{R}^{2} \\
\text { Separation factor }\end{array}$ & $\begin{array}{c}555.6 \\
0.0833 \\
0.9981 \\
0.02-0.71\end{array}$ & $\begin{array}{r}294.1 \\
0.0854 \\
0.9963 \\
0.02-0.07\end{array}$ & $\begin{array}{c}222.2 \\
0.1372 \\
0.9739 \\
0.014-0.59\end{array}$ & $\begin{array}{c}185.19 \\
0.1013 \\
0.9732 \\
0.019-0.66\end{array}$ \\
\hline \multicolumn{6}{|l|}{ Freundlich Isotherm } \\
\hline $\log q=\log K+\frac{1}{n} \log C_{2}$ & $\begin{array}{l}1 / \mathrm{n} \\
\mathrm{K}(\mathrm{mg} / \mathrm{g})(\mathrm{L} / \mathrm{mg})^{1 / \mathrm{n}} \\
\mathrm{R}^{2}\end{array}$ & $\begin{array}{l}0.4271 \\
59.01 \\
0.9541\end{array}$ & $\begin{array}{l}0.7233 \\
10.15 \\
0.9289\end{array}$ & $\begin{array}{l}3.7805 \\
0.3975 \\
0.9882\end{array}$ & $\begin{array}{l}0.7041 \\
14.3 \\
0.9746\end{array}$ \\
\hline D-R Isotherm & & & & & \\
\hline $\begin{array}{l}\ln Q=\ln Q_{m}-k \varepsilon^{2} \\
E=(2 k)^{-0.5}\end{array}$ & $\begin{array}{l}\mathrm{E}(\mathrm{kJ} / \mathrm{mol}) \\
Q_{\mathrm{m}}(\mathrm{mol} / \mathrm{g}) \\
\mathbf{k}\left(\mathrm{mol}^{2} / \mathbf{k J}^{2}\right) \\
R^{2}\end{array}$ & $\begin{array}{l}11.95 \\
0.0041 \\
0.0035 \\
0.9741\end{array}$ & $\begin{array}{l}9.535 \\
0.0079 \\
0.0055 \\
0.8421\end{array}$ & $\begin{array}{l}10.43 \\
0.0044 \\
0.0046 \\
0.9351\end{array}$ & $\begin{array}{l}4.360 \\
4.251 \times 10^{6} \\
0.0263 \\
0.95\end{array}$ \\
\hline
\end{tabular}

$\mathrm{C}_{2}$ is the equilibrium concentration of the solution $(\mathrm{mg} / \mathrm{L})$, $\mathrm{q}$ is the amount of adsorbed dye/amount of adsorbent $(\mathrm{mg} / \mathrm{g}), \mathrm{b}$ is the Langmuir constant $(\mathrm{L} / \mathrm{mg}), \mathrm{Q}_{\max }$ is the monolayer adsorption capacity $(\mathrm{mg} / \mathrm{g}), \mathrm{K}$ is the Freundlich constant $\left((\mathrm{mg} / \mathrm{g})(\mathrm{L} / \mathrm{mg})^{1 / \mathrm{n}}\right)$, and $1 / \mathrm{n}$ is a dimensionless Freundlich constant for the intensity of the adsorbent, $\varepsilon$ (Polanyi potential) is $\left(\mathbf{R T} \ln \left(1+\mathbf{1} / \mathbf{C}_{2}\right)\right)$, $\mathrm{Q}$ is the amount of dye adsorbed per unit weight of adsorbent $(\mathrm{mol} / \mathrm{g}), \mathrm{Q}_{\mathrm{m}}$ is the adsorption capacity $(\mathrm{mol} / \mathrm{g}), \mathrm{k}$ is a constant related to adsorption energy $\left.\left(\mathrm{mol}^{2} / \mathrm{kJ}\right)^{2}\right), \mathrm{R}$ is the gas constant $(\mathrm{kJ} / \mathrm{mol} \mathrm{K})$, and $\mathrm{T}$ is the absolute temperature $(\mathrm{K})$.

isotherm expresses the mechanism of adsorption onto a heterogeneous surface. ${ }^{42}$ In order to evaluate the adsorption isotherm, the used parameters were $25 \mathrm{~mL}$ of volume, an adsorbent dose of BG and MG 0.4 and $0.6 \mathrm{~g} / \mathrm{L}$ for SW800 and 1.2 and $2.4 \mathrm{~g} / \mathrm{L}$ for SW500, respectively and 24 $\mathrm{h}$ of contact time. Initial concentrations were in the range of $5-500 \mathrm{mg} / \mathrm{L}$. Results and related equations were presented in Table 2 and Figure 8.

The correlation coefficients were evaluated to find the best fit isotherm model for the system. As seen in Table 
2 , the highest correlation coefficient $\left(\mathrm{R}^{2}\right)$ of BG was obtained for the Langmuir isotherm model while the highest $\mathrm{R}^{2}$ of MG was for Freundlich isotherm model. Thus, the adsorption of BG by SW500 and SW800 were monolayer on homogeneous sites. However, the adsorption of MG was a multilayer adsorption on a heterogeneous site. The maximum monolayer adsorption capacities of BG and MG were calculated to be $294.1 \mathrm{mg} / \mathrm{g}$ and $185.19 \mathrm{mg} / \mathrm{g}$ for SW500 and $555.6 \mathrm{mg} / \mathrm{g}$ and $222.3 \mathrm{mg} / \mathrm{g}$ for SW800. $1 / \mathrm{n}$ values indicate the adsorption intensity. The higher $1 / \mathrm{n}$ values mean the higher affinity between the dye molecules and adsorbent. ${ }^{38}$ The separation factor $\left(\mathrm{R}_{\mathrm{L}}\right)$ shows whether the adsorption is favorable $\left(0<\mathrm{R}_{\mathrm{L}}<1\right)$, unfavorable $\left(\mathrm{R}_{\mathrm{L}}>\right.$ $1)$, linear $\left(R_{L}=1\right)$ or irreversible $\left(R_{L}=0\right) .{ }^{43}$ The separation factor is calculated by the equations given:

$$
\mathrm{R}_{\mathrm{L}}=\left(\frac{1}{1+\mathrm{bC}_{1}}\right)
$$

where $C_{1}$ is the initial concentration and $b$ is the Langmuir isotherm constant. Seeing that the $\mathrm{R}_{\mathrm{L}}$ values were in the range of $0-1$, adsorption was favorable for both the adsorbents.

The mechanism of adsorption can be determined by assessing $\mathrm{E}$ value $(\mathrm{kJ} / \mathrm{mol})$. The mean free energy of adsorption (E), which is defined as the free energy change when one mole of ion is transferred to the surface of a solid from the infinite space in the solution. Physical adsorption is val- id if the value is below $8 \mathrm{~kJ} / \mathrm{mol}$. When the $\mathrm{E}$ value is between $8 \mathrm{~kJ} / \mathrm{mol}$ and $16 \mathrm{~kJ} / \mathrm{mol}$, chemisorption or ion exchange occurs. ${ }^{44}$ Since the values of BG $(11.95 ; 9.54 \mathrm{~kJ} / \mathrm{mol}$ for SW800; SW500) and MG (10.43; $4.36 \mathrm{~kJ} / \mathrm{mol}$ for SW800; SW500) were between 8 and $16 \mathrm{~kJ} / \mathrm{mol}$, the presence of chemisorption or ion exchange could be mentioned.

\section{2. 7. Adsorption Kinetic Studies}

In this study, to understand the adsorption mechanism, three simplified kinetic models were elucidated: Lagergren pseudo first order, pseudo second order and intraparticle diffusion model. ${ }^{41}$ These models define the stages of the adsorption to be external film diffusion, adsorption, and intraparticle diffusion. ${ }^{45}$ Figure 9 presents the time effects on the adsorption, pseudo first-order kinetic model, pseudo second-order kinetic model, and intraparticle diffusion kinetic model for the adsorption of BG and MG onto SW500 and SW800 adsorbents. The calculated parameters belonging to the kinetic models are depicted in Table 3. As can be seen from Table 3 , the closest $\mathrm{R}^{2}$ values to unity were obtained for the pseudo second order kinetic model for the studied dyes. The calculated $\left(\mathrm{q}_{\mathrm{e}, \mathrm{cal}}\right)$ and experimental $\left(\mathrm{q}_{\mathrm{e}, \exp }\right)$ values of adsorption capacities of BG and MG were very close to each other for the pseudo second order kinetic model. These findings indicated the adsorption fitted well with pseudo second order kinetic model and adsorption was chemisorption controlled. ${ }^{46}$ In the a)

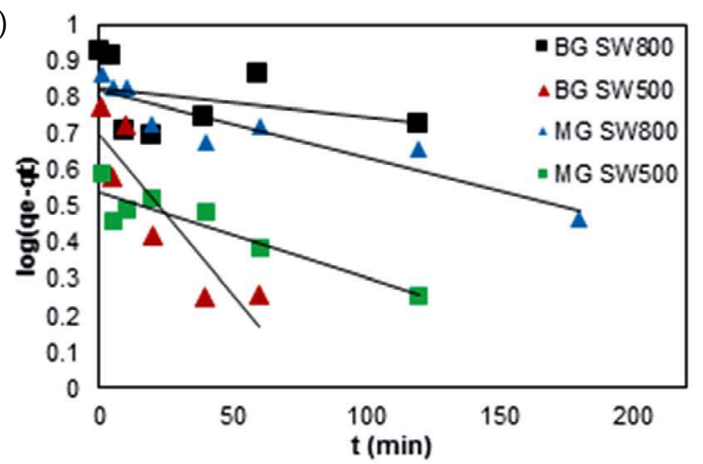

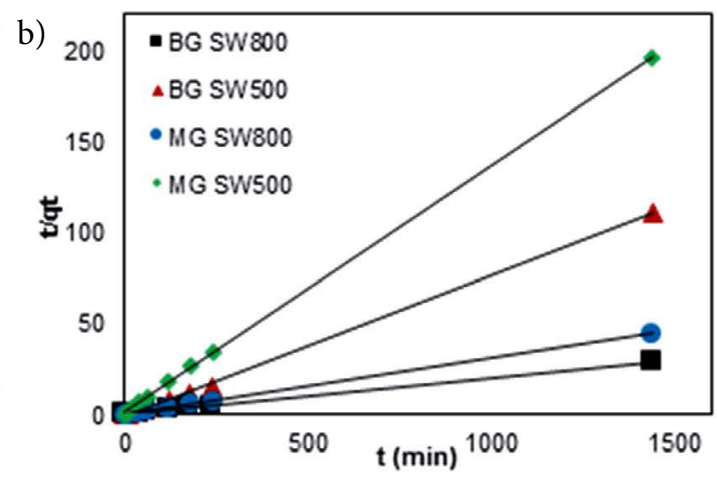

c)

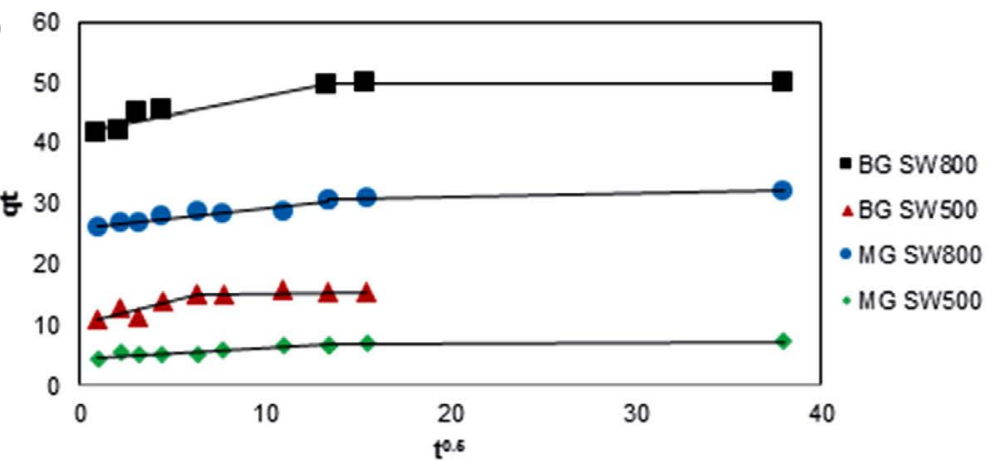

Figure 9. Kinetic studies for BG and MG adsorption a) pseudo first-order kinetic model, b) pseudo second-order kinetic model, c) intraparticle diffusion kinetic model (initial dye concentration $20 \mathrm{mg} / \mathrm{L}$, volume $25 \mathrm{~mL}$, adsorbent dose of BG and MG: 0.4 and $0.6 \mathrm{~g} / \mathrm{L}$ for SW800 and, 1.2 and $2.4 \mathrm{~g} / \mathrm{L}$ for SW500, contact time $24 \mathrm{~h}$, temperature $25^{\circ} \mathrm{C}, \mathrm{n}=3$ ) 
Table 3. The constants of the pseudo first-order, pseudo second-order kinetic models, and intraparticle kinetic model for BG and MG removal ( $\mathrm{n}=3$ ).

\begin{tabular}{|c|c|c|c|c|c|c|c|c|}
\hline \multirow[t]{2}{*}{ Kinetic Models } & \multicolumn{3}{|c|}{$\begin{array}{c}\text { Adsorbent } \\
\text { SW800 }\end{array}$} & \multirow[b]{2}{*}{$\mathbf{R}^{2}$} & \multicolumn{3}{|c|}{ SW500 } & \multirow[b]{2}{*}{$\mathbf{R}^{2}$} \\
\hline & $\begin{array}{c}\mathrm{q}_{\mathrm{e}, \exp } \\
(\mathrm{mg} / \mathrm{g})\end{array}$ & $\begin{array}{c}\mathbf{q}_{\mathrm{e}, \mathrm{cal}} \\
(\mathrm{mg} / \mathrm{g})\end{array}$ & $\begin{array}{c}\mathbf{k}_{1} \\
(1 / \mathbf{m i n})\end{array}$ & & $\begin{array}{c}\mathrm{q}_{\mathrm{e}, \exp } \\
(\mathrm{mg} / \mathrm{g})\end{array}$ & $\begin{array}{c}\mathrm{q}_{\mathrm{e}, \mathrm{cal}} \\
(\mathrm{mg} / \mathrm{g})\end{array}$ & $\begin{array}{c}\mathbf{k}_{2} \\
(\mathrm{~g} / \mathrm{mgmin})\end{array}$ & \\
\hline \multicolumn{9}{|l|}{ Pseudo first order } \\
\hline \multicolumn{9}{|l|}{$\log \left(q_{e}-q_{t}\right)=\log q_{e}-\frac{k_{1} t}{2.303}$} \\
\hline $\mathrm{BG}$ & 49.67 & 6.668 & 0.00184 & 0.1121 & 14.84 & 5.041 & 0.0205 & 0.7996 \\
\hline MG & 33.33 & 6.637 & 0.00438 & 0.8687 & 8.33 & 3.472 & 0.0053 & 0.8469 \\
\hline \multicolumn{9}{|l|}{ Pseudo second order } \\
\hline \multicolumn{9}{|l|}{$\frac{t}{q_{t}}=\frac{1}{k_{2} q_{e}^{2}}+\frac{t}{q_{e}}$} \\
\hline BG & 49.67 & 50 & 0.005076 & 0.9999 & 14.84 & 12.89 & -0.00735 & 0.9990 \\
\hline MG & 33.33 & 32.26 & 0.005128 & 0.9999 & 8.33 & 7.369 & 0.01363 & 0.998 \\
\hline \multicolumn{9}{|c|}{ Intraparticle diffusion model } \\
\hline $\mathrm{q}_{\mathrm{t}}=\mathbf{k}_{\mathrm{int}} \mathbf{t}^{0.5}+\mathrm{I}$ & & $\begin{array}{c}\mathrm{I} \\
(\mathrm{mg} / \mathrm{g})\end{array}$ & $\begin{array}{c}\mathrm{k} \\
\left(\mathrm{mg} / \mathrm{gmin}^{0.5}\right)\end{array}$ & $\mathbf{R}^{2}$ & & $\begin{array}{c}\text { I } \\
(\mathrm{mg} / \mathrm{g})\end{array}$ & $\begin{array}{c}\mathrm{k} \\
\left(\mathrm{mg} / \mathrm{gmin}^{0.5}\right)\end{array}$ & $\mathbf{R}^{2}$ \\
\hline \multirow[t]{2}{*}{ BG } & & Step 1 & 41.63 & 0.6047 & 0.8893 & 10.19 & 0.7498 & 0.7789 \\
\hline & & Step 2 & 49.483 & 0.0082 & 0.2363 & 14.522 & 0.0647 & 0.5396 \\
\hline \multirow[t]{2}{*}{ MG } & & Step 1 & 25.967 & 0.3118 & 0.8969 & 4.5719 & 0.1621 & 0.8509 \\
\hline & & Step 2 & 29.652 & 0.0654 & 0.9851 & 6.5568 & 0.0207 & 0.7878 \\
\hline
\end{tabular}

$\mathrm{q} e$ and $\mathrm{qt}$ indicate the adsorption capacity at equilibrium $(\mathrm{mg} / \mathrm{g})$ and at time $\mathrm{t} ; \mathrm{k} 1$ and $\mathrm{k} 2$ are the pseudo first-order $(1 / \mathrm{min})$ and pseudo second-order rate constants ( $\mathrm{g} / \mathrm{mg} \mathrm{min})$; $\mathrm{t}$ is the contact time $(\mathrm{min})$ and $\mathrm{kint}\left(\mathrm{mg} / \mathrm{g} \mathrm{min}{ }^{0.5}\right)$ and $\mathrm{I}(\mathrm{mg} / \mathrm{g}$ ) are the intraparticle diffusion constants.

intraparticle diffusion model, the plot $\mathrm{q}_{\mathrm{t}}$ versus $\mathrm{t}^{0.5}$ gives $\mathrm{k}$ and I as slope and intercept, respectively. The intercept indicates the effect of the boundary layer thickness. The higher the intercept length, the more the adsorption is boundary layer controlled. ${ }^{46}$ Also, if the line passes through the origin $(I=0)$, the rate limiting mechanism is solely controlled by the intraparticle diffusion. Thus, it was concluded that the intraparticle diffusion was not the only rate limiting step. Since two separate regions were obtained for both the adsorbents, the adsorption process was affected by two or more steps. The initial region is ascribed to the bulk diffusion while the second to the intraparticle diffusion. ${ }^{38}$

\section{Conclusion}

The adsorbents used in this study were obtained from the sandpaper wastes. Hazardous and toxic reagents were not used during the preparation of the adsorbents. Thus, environmentally friendly adsorbents were obtained. Furthermore, the removal of brilliant green from aqueous solutions was successfully carried out using both the adsorbents. Optimization studies $(\mathrm{pH}$, adsorbent dose, contact time, and initial concentration etc.) were carried out to investigate the removal performance of both adsorbents. According to the $\mathrm{pH}$ study, $\mathrm{SW} 800$ provided a wider $\mathrm{pH}$ range than that of SW500 for both dyes. The optimum adsorbent doses of BG and MG were selected as 0.4 and $0.6 \mathrm{~g} / \mathrm{L}$ for SW800 while 1.2 and $2.4 \mathrm{~g} / \mathrm{L}$ for SW500, respectively. The removal efficiencies of $B G$ and $M G$ reached a plateau after $120 \mathrm{~min}$ and $180 \mathrm{~min}$ for SW500 and $180 \mathrm{~min}$ and $240 \mathrm{~min}$ for SW800, respectively. The adsorption kinetics of the dyes fitted well with the pseudo second-order kinetic model. The adsorption of the BG showed good agreement with the Langmuir isotherm model and indicated monolayer adsorption on homogeneous sites. However, it was found that the adsorption of the MG obeyed the Freundlich isotherm model. The values of $\mathrm{E}$ indicated the adsorption mechanism of dyes could be chemical or through ion exchange. The adsorption of BG and MG were found to be favorable for both SW500 and SW800. The thermodynamic studies indicated that the process was endothermic, spontaneous, and feasible. The comparison of the maximum BG and MG adsorption capacities with the reported adsorbents in the literature can be found in Table 4. By comparing the maximum adsorption capacities in Table 4 , the highest capacity values belonged to the sandpaper waste. As a result, environmentally friendly adsorbents were developed that facilitate fast and efficient removal.

\section{Acknowledgments}

Authors would like to thank to Münevver Özalp and Elif Cansu Tanriverdi for their help on laboratory study.

\section{Funding}

This research did not receive any specific grant from funding agencies in the public, commercial, or not-forprofit sectors. 
Table 4 Comparison of the maximum adsorption capacities of BG and MG with the reported adsorbents in the literature.

\begin{tabular}{|c|c|c|c|c|c|c|c|c|c|}
\hline BG & & & & & MG & & & & \\
\hline Adsorbent & $\begin{array}{l}\text { Capacity } \\
(\mathrm{mg} / \mathrm{g})\end{array}$ & Isotherm & $\begin{array}{l}\text { Kinetic } \\
\text { model }\end{array}$ & Ref. & Adsorbent & $\begin{array}{l}\text { Capacity } \\
(\mathrm{mg} / \mathrm{g})\end{array}$ & Isotherm & $\begin{array}{c}\text { Kinetic } \\
\text { model }\end{array}$ & Ref. \\
\hline Tannin gel (TG) & 8.55 & Langmuir & $\begin{array}{c}\text { Pseudo } \\
\text { second order }\end{array}$ & 6 & AMP clay & 130.64 & Langmuir & $\begin{array}{l}\text { Pseudo } \\
\text { first order }\end{array}$ & 1 \\
\hline $\begin{array}{l}\text { Amine modified } \\
\text { TG }\end{array}$ & 2.41 & Langmuir & $\begin{array}{c}\text { Pseudo } \\
\text { second order }\end{array}$ & 6 & $\begin{array}{l}\text { Coconot coir } \\
\text { activated carbon }\end{array}$ & 27.44 & $\begin{array}{l}\text { Langmuir } \\
\text { Freundlich }\end{array}$ & $\begin{array}{c}\text { Pseudo } \\
\text { second order }\end{array}$ & 7 \\
\hline Acorn & 2.01 & Langmuir & $\begin{array}{c}\text { Pseudo } \\
\text { second order }\end{array}$ & 46 & Rattan sawdust & 62.71 & Langmuir & $\begin{array}{l}\text { Pseudo } \\
\text { first order }\end{array}$ & 12 \\
\hline $\begin{array}{l}\text { Peganum } \\
\text { harmala-L seeds }\end{array}$ & 35.97 & Langmuir & $\begin{array}{c}\text { Pseudo } \\
\text { second order }\end{array}$ & 3 & $\begin{array}{l}\text { EM based } \\
\text { compost }\end{array}$ & 159.22 & Sips & $\begin{array}{c}\text { Pseudo } \\
\text { second order }\end{array}$ & 13 \\
\hline Saklıkent mud & 1.18 & Langmuir & $\begin{array}{c}\text { Pseudo } \\
\text { second order }\end{array}$ & 45 & Potato peel & 35.61 & $\begin{array}{l}\text { Redlich- } \\
\text { Peterson }\end{array}$ & $\begin{array}{l}\text { Pseudo- } \\
\text { nth order }\end{array}$ & 50 \\
\hline $\begin{array}{l}\text { White rice } \\
\text { husk ash }\end{array}$ & 85.56 & - & $\begin{array}{c}\text { Pseudo } \\
\text { second order }\end{array}$ & 16 & $\mathrm{GO}-\mathrm{Fe}_{3} \mathrm{O}_{4}$ & 160.7 & $\begin{array}{l}\text { Langmuir } \\
\text { Freundlich }\end{array}$ & $\begin{array}{c}\text { Pseudo } \\
\text { second order }\end{array}$ & 51 \\
\hline Red clay & 125 & $\begin{array}{l}\text { Redlich- } \\
\text { Peterson }\end{array}$ & $\begin{array}{c}\text { Pseudo } \\
\text { second order }\end{array}$ & 35 & $\begin{array}{l}\text { Citrus limetta } \\
\text { peel }\end{array}$ & 8.733 & $\mathrm{D}-\mathrm{R}$ & $\begin{array}{c}\text { Pseudo } \\
\text { second order }\end{array}$ & 22 \\
\hline Kaolin & 65.42 & Langmuir & $\begin{array}{c}\text { Pseudo } \\
\text { second order }\end{array}$ & 2 & Zea mays cob & 16.72 & $\mathrm{D}-\mathrm{R}$ & $\begin{array}{c}\text { Pseudo } \\
\text { second order }\end{array}$ & 22 \\
\hline $\begin{array}{l}\mathrm{NaOH} \text { treated } \\
\text { saw dust }\end{array}$ & 58.48 & $\begin{array}{l}\text { Redlich- } \\
\text { Peterson } \\
\text { and Temkin }\end{array}$ & $\begin{array}{c}\text { Pseudo } \\
\text { second order }\end{array}$ & 14 & $\begin{array}{l}\text { Organically } \\
\text { modified } \\
\text { hydroxyapatite }\end{array}$ & 188.18 & Langmuir & - & 21 \\
\hline $\begin{array}{l}\mathrm{Ni} / \mathrm{Ni}_{\mathrm{X}} \mathrm{B} \\
\text { nanoparticle- } \\
\text { coated resin }\end{array}$ & 147.1 & Langmuir & $\begin{array}{c}\text { Pseudo } \\
\text { second order }\end{array}$ & 49 & SW800 & 222.2 & & $\begin{array}{c}\text { Pseudo } \\
\text { second order }\end{array}$ & $\begin{array}{l}\text { This } \\
\text { study }\end{array}$ \\
\hline SW800 & 555.6 & Langmuir & $\begin{array}{c}\text { Pseudo } \\
\text { second order }\end{array}$ & $\begin{array}{l}\text { This } \\
\text { study }\end{array}$ & SW500 & 185.19 & & $\begin{array}{c}\text { Pseudo } \\
\text { second order }\end{array}$ & $\begin{array}{l}\text { This } \\
\text { study }\end{array}$ \\
\hline SW500 & 294.1 & Langmuir & $\begin{array}{c}\text { Pseudo } \\
\text { second order }\end{array}$ & $\begin{array}{l}\text { This } \\
\text { study }\end{array}$ & & & & & \\
\hline
\end{tabular}

\section{References}

1. Y.-C. Lee, E. J. Kim, J.-W. Yang and H.-J. Shin, J. Hazard. Mater. 2011, 192, 62-70.

2. B. K. Nandi, A. Goswami and M. K. Purkait, J. Hazard. Mater. 2009, 161, 387-395. DOI:10.1016/j.jhazmat.2008.03.110

3. S. Agarwal, V. K. Gupta, M. Ghasemi and J. Azimi-Amin, J. Mol. Liq. 2017, 231, 296-305.

DOI:10.1016/j.molliq.2017.01.097

4. L. Kong, F. Qiu, Z. Zhao, X. Zhang, T. Zhang, J. Pan and D. Yang, J. Clean. Prod. 2016, 137, 51-59.

DOI:10.1016/j.jclepro.2016.07.067

5. M. Oplatowska, R. F. Donnelly, R. J. Majithiya, D. Glenn Kennedy and C. T. Elliott, Food Chem. Toxicol. 2011, 49, 18701876. DOI:10.1016/j.fct.2011.05.005

6. N. Akter, A. Hossain, M. J. Hassan, M. K. Amin, M. Elias, M. M. Rahman, A. M. Asiri, I. A. Siddiquey and M. A. Hasnat, J. Environ. Chem. Eng. 2016, 4, 1231-1241.

DOI:10.1016/j.jece.2016.01.013

7. Uma, S. Banerjee and Y. C. Sharma, J. Ind. Eng. Chem. 2013, 19, 1099-1105. DOI:10.1016/j.jiec.2012.11.030

8. A. A. Adeyemo, I. O. Adeoye and O. S. Bello, Appl. Water Sci. 2017, 7, 543-568. DOI:10.1007/s13201-015-0322-y
9. L. Bulgariu, L. B. Escudero, O. S. Bello, M. Iqbal, J. Nisar, K. A. Adegoke, F. Alakhras, M. Kornaros and I. Anastopoulos, J. Mol. Liq. 2019, 276, 728-747.

DOI:10.1016/j.molliq.2018.12.001

10. A. Kausar, M. Iqbal, A. Javed, K. Aftab, Z.-H. Nazli, H. N. Bhatti and S. Nouren, J. Mol. Liq. 2018, 256, 395-407.

DOI:10.1016/j.molliq.2018.02.034

11. V. Katheresan, J. Kansedo and S. Y. Lau, J. Environ. Chem. Eng. 2018, 6, 4676-4697. DOI:10.1016/j.jece.2018.06.060

12. B. H. Hameed and M. I. El-Khaiary, J. Hazard. Mater. 2008, 159, 574-579. DOI:10.1016/j.jhazmat.2008.02.054

13. T. Bhagavathi Pushpa, J. Vijayaraghavan, S. J. Sardhar Basha, V. Sekaran, K. Vijayaraghavan and J. Jegan, Ecotoxicol. Environ. Saf. 2015, 118, 177-182. DOI:10.1016/j.ecoenv.2015.04.033

14. V. S. Mane and P. V. V. Babu, Desalination 2011, 273, 321329. DOI:10.1016/j.desal.2011.01.049

15. V. K. Gupta, B. Gupta, A. Rastogi, S. Agarwal and A. Nayak, J. Hazard. Mater. 2011, 186, 891-901.

DOI:10.1016/j.jhazmat.2010.11.091

16. M. P. Tavlieva, S. D. Genieva, V. G. Georgieva and L. T. Vlaev, J. Colloid Interface Sci. 2013, 409, 112-122.

DOI:10.1016/j.jcis.2013.07.052 
17. K. G. Bhattacharyya and A. Sarma, Dye. Pigment. 2003, 57, 211-222. DOI:10.1016/S0143-7208(03)00009-3

18. T. Uysal, G. Duman, Y. Onal, I. Yasa and J. Yanik, J. Anal. Appl. Pyrolysis 2014, 108, 47-55.

DOI:10.1016/j.jaap.2014.05.017

19. M. Baghdadi, B. A. Soltani and M. Nourani, J. Ind. Eng. Chem. 2017, 55, 128-139. DOI:10.1016/j.jiec.2017.06.037

20. Sandpaper, https://en.wikipedia.org/wiki/Sandpaper, (accessed 1 November 2018).

21. A. A. El-Zahhar and N. S. Awwad, J. Environ. Chem. Eng. 2016, 4, 633-638. DOI:10.1016/j.jece.2015.12.014

22. H. Singh, G. Chauhan, A. K. Jain and S. K. Sharma, J. Environ. Chem. Eng. 2017, 5, 122-135.

DOI:10.1016/j.jece.2016.11.030

23. S. Milicevic, T. Boljanac, S. Martinovic, M. Vlahovic, V. Milosevic and B. Babic, Fuel Process. Technol. 2012, 95, 1-7. DOI:10.1016/j.fuproc.2011.11.005

24. M. J. Rwiza, S. Y. Oh, K. W. Kim and S. D. Kim, Chemosphere 2018, 195, 135-145. DOI:10.1016/j.chemosphere.2017.12.043

25. N. Kataria and V. K. Garg, J. Environ. Chem. Eng. 2017, 5, 5420-5428. DOI:10.1016/j.jece.2017.10.035

26. C. L. Lu, J. G. Lv, L. Xu, X. F. Guo, W. H. Hou, Y. Hu and H. Huang, Nanotechnology 2009, 20, 215604-215612.

DOI:10.1088/0957-4484/20/21/215604

27. H. Xia, L. Chen and Y. Fang, Sep. Sci. Technol. 2013, 48, 26812687. DOI:10.1080/01496395.2013.805340

28. L. Dai, W. Zhu, L. He, F. Tan, N. Zhu, Q. Zhou, M. He and G. Hu, Bioresour. Technol. 2018, 267, 510-516.

DOI:10.1016/j.biortech.2018.07.090

29. K.-W. Jung, B. H. Choi, M.-J. Hwang, T.-U. Jeong and K.-H. Ahn, Bioresour. Technol. 2016, 219, 185-195.

DOI:10.1016/j.biortech.2016.07.098

30. S. Chowdhury and P. Saha, Chem. Eng. J. 2010, 164, 168-177. DOI:10.1016/j.cej.2010.08.050

31. I. A. Aguayo-Villarreal, L. A. Ramírez-Montoya, V. Hernández-Montoya, A. Bonilla-Petriciolet, M. A. Montes-Morán and E. M. Ramírez-López, Ind. Crops Prod. 2013, 48, 89-97. DOI:10.1016/j.indcrop.2013.04.009

32. N. Fiol and I. Villaescusa, Environ. Chem. Lett. 2009, 7, 7984. DOI:10.1007/s10311-008-0139-0

33. F. de Castro Silva, M. M. F. da Silva, L. C. B. Lima, J. A. Osajima and E. C. da Silva Filho, Int. J. Biol. Macromol. 2018, 114, 470-478. DOI:10.1016/j.ijbiomac.2018.03.089

34. A. B. Karim, B. Mounir, M. Hachkar, M. Bakasse and A. Yaacoubi, J. Hazard. Mater. 2009, 168, 304-309.

\section{DOI:10.1016/j.jhazmat.2009.02.028}

35. M. Saif, U. Rehman, M. Munir, M. Ashfaq, M. F. Nazar, M. Danish and J. Han, Chem. Eng. J. 2013, 228, 54-62. DOI:10.1016/j.cej.2013.04.094

36. E. C. Lima, A. Hosseini-Bandegharaei, J. C. Moreno-Piraján and I. Anastopoulos, J. Mol. Liq. 2019, 273, 425-434. DOI:10.1016/j.molliq.2018.10.048

37. Y. Bulut and H. Aydin, Desalination 2006, 194, 259-267. DOI:10.1016/j.desal.2005.10.032

38. V. S. Mane, I. D. Mall and V. C. Srivastava, J. Environ. Manag. 2007, 84, 390-400. DOI:10.1016/j.jenvman.2006.06.024

39. S. K. Srivastava, V. K. Gupta, M. K. Dwivedi and S. Jain, Anal. Proc. Incl. Anal. Commun. 1995, 32, 21-23. DOI:10.1039/AI9953200021

40. I. Langmuir, J. Am. Chem. Soc. 1918, 40, 1361-1403. DOI: $10.1021 / \mathrm{ja} 02242 \mathrm{a} 004$

41. T. D. Çiftçi, Cogent Chem. 2017, 3, 1-15. DOI: $10.1080 / 23312009.2017 .1284296$

42. M. Ghasemi, M. Naushad, N. Ghasemi and Y. Khosravi-fard, J. Ind. Eng. Chem. 2014, 20, 2193-2199.

DOI:10.1016/j.jiec.2013.09.050

43. A. K. Meena, K. Kadirvelu, G. K. Mishraa, C. Rajagopal and P. N. Nagar, J. Hazard. Mater. 2008, 150, 619-625.

DOI:10.1016/j.jhazmat.2007.05.011

44. N. K. Amin, J. Hazard. Mater. 2009, 165, 52-62. DOI:10.1016/j.jhazmat.2008.09.067

45. Y. Kismir and A. Z. Aroguz, Chem. Eng. J. 2011, 172, 199206. DOI:10.1016/j.cej.2011.05.090

46. M. Ghaedi, H. Hossainian, M. Montazerozohori, A. Shokrollahi, F. Shojaipour, M. Soylak and M. K. Purkait, Desalination 2011, 281, 226-233. DOI:10.1016/j.desal.2011.07.068

47. N. Akter, M. A. Hossain, M. J. Hassan, M. K. Amin, M. Elias, M. M. Rahman, A. M. Asiri, I. A. Siddiquey and M. A. Hasnat, J. Environ. Chem. Eng. 2016, 4, 1231-1241. DOI:10.1016/j.jece.2016.01.013

48. M. S. Raghu, K. Y. Kumar, M. K. Prashanth, B. P. Prasanna, R. Vinuth and C. B. Pradeep Kumar, J. Water Process Eng. 2017, 17, 22-31. DOI:10.1016/j.jwpe.2017.03.001

49. M. Çınar, Y. İşlek Coşkun and T. Deniz Çiftçi, Turkish J. Chem. 2018, 42, 505-519.

50. E-K. Guechi and O. Hamdaoui, Arab. J. Chem. 2016, 9, 416424. DOI:10.1016/j.arabjc.2011.05.011

51. M. S. Raghu, K.Y. Kumar, M.K. Prashanth et al., J. Water Process Eng. 2017, 17, 22-31. DOI:10.1016/j.jwpe.2017.03.001

\section{Povzetek}

Odpadke brusilnega papirja smo po pirolizi na 500 in kalcinaciji na 600 uporabili za odstranjevanje kationskih barvil briljantno zeleno in malahitno zeleno iz vodnih raztopin. Adsorpcijsko ravnotežje smo poskusili opisati z Langmuir-jevo, Freundlich-ovo, in Dubinin-Radushkevich-ovo izotermo ter izvedli termodinamske študije. Adsorbcijo na briljantno zeleno smo najbolje opisali z Langmuir-jevo izotermo, adsorpcijo na malahitno zeleno pa z Freundlich-ovo. Izkazalo se je, da je adsorpcija endotermna. E vrednost pridobljena iz Dubinin-Radushkevich-ove izoterme je pokazala, da gre za kemijsko adsorpcijo. Kinetiko adsorpcije smo preučili s tremi kinetični modeli (psevdo prvi-red, psevdo drugi-red reakcije in modelom znotraj-delčne difuzije) in pokazali, da model psevdo-drugega reda najbolje opiše adsorpcijo na obe barvili. 